\title{
Factor Affecting Gel Time/Process-Ability of Urea Formaldehyde Resin Based Wood Adhesives
}

\author{
Ravindra V. Gadhave, Prakash A. Mahanwar, Pradeep T. Gadekar \\ Department of Polymer and Surface Engineering, Institute of Chemical Technology (ICT), Mumbai, India \\ Email: ravi.gadhave3@gmail.com
}

How to cite this paper: Gadhave, R.V., Mahanwar, P.A. and Gadekar, P.T. (2017) Factor Affecting Gel Time/Process-Ability of Urea Formaldehyde Resin Based Wood Adhesives. Open Journal of Polymer Chemistry, 7, 33-42.

https://doi.org/10.4236/ojpchem.2017.72003

Received: July 20, 2016

Accepted: May 28, 2017

Published: May 31, 2017

Copyright $\odot 2017$ by authors and Scientific Research Publishing Inc. This work is licensed under the Creative Commons Attribution International License (CC BY 4.0).

http://creativecommons.org/licenses/by/4.0/ (c) (i) Open Access

\begin{abstract}
Urea-formaldehyde (UF) resin presents the most utilized adhesive system in the manufacture of plywood, particleboard and fiberboard. At the temperatures above $100^{\circ} \mathrm{C}$ in the presence of hardener, this resin undergoes crosslinking reaction and the formation of three dimensional cross linked structures takes place and bonding of wood particles in a hot press [1]. UF powder resins show high reactivity and good performance in the production and by their low price; however they lack in water resistance of the hardened resin [2]. Urea-formaldehyde (UF) resins are the most important type of adhesive resins for the production of wood based panels but process-ability and curing behavior of urea formaldehyde resin depended on various factors related to resin properties, types of wood and their properties, amount \& type of catalyst, types and amount of polymers addition and environmental conditions [3]. This factor decides the process-ability of UF resin based composite during manufacturing of plywood, particle board and fiberboard. In this review paper, various factors affecting gel time and process-ability of UF resin based wood composite are reviewed.
\end{abstract}

\section{Keywords}

Urea Formaldehyde Resins, Catalysts, Gel Time, Wood, pH, Polyvinyl Acetate, Composite

\section{Introduction}

Urea-formaldehyde (UF) resin is one of the most important thermosetting adhesive systems of interior class with the largest tonnage consumption (approximately 1 million metric tons/annum) in wood processing industry and particularly in wood-based panel (WBP) production [4]. The resin is used in the pro- 
duction of an adhesive for bonding particleboard (61\%), medium density fiberboard (27\%), hardwood plywood (5\%) and a laminating adhesive for bonding (7\%) for example, furniture case goods, overlays to panels and interior flush doors [2].

It's relatively low costing and excellent processing features enable the production of panels with required performance and competitive price. UF resin has the main disadvantage of poor resistance to moisture and water, especially at higher temperatures thus it is not recommended to use of UF resins for exterior applications [5] [6].

Ammonium chloride $\left(\mathrm{NH}_{4} \mathrm{Cl}\right)$ is a common and effective hardener used for accelerating UF-resin curing. In this case, a higher molar ratio (1:1.6 - 1:2) of the UF resin plays a role in supplying enough free formaldehyde to the system to react with $\mathrm{NH}_{4} \mathrm{Cl}$ and release $\mathrm{HCl}$. However, the UF resins currently used in the wood product industry are all lower molar ratio resins (normally 1:1.05 to 1:1.1). The limited free formaldehyde in the system limits the release of $\mathrm{HCl}$ by reacting with added $\mathrm{NH}_{4} \mathrm{Cl}$ [7] [8] [9] [10] [11]. In presence of acid catalyst, urea formaldehyde powder resin undergoes following reactions is shown in Figure 1.

-Methylene bridges between amido nitrogens by the reaction of methylol and amino groups on reacting molecules.

-Methylene ether linkages by the reaction of two methylol groups.

-Methylene linkages from methylene ether linkages by the splitting out of formaldehyde.

-Methylene linkages by the reaction of methylol groups splitting out water and formaldehyde in the process.

In Wood based composite production influence of wood component is also important in the process of manufacturing. Change in fiber source, may have detrimental effects on the mechanical and physical properties of the panel and
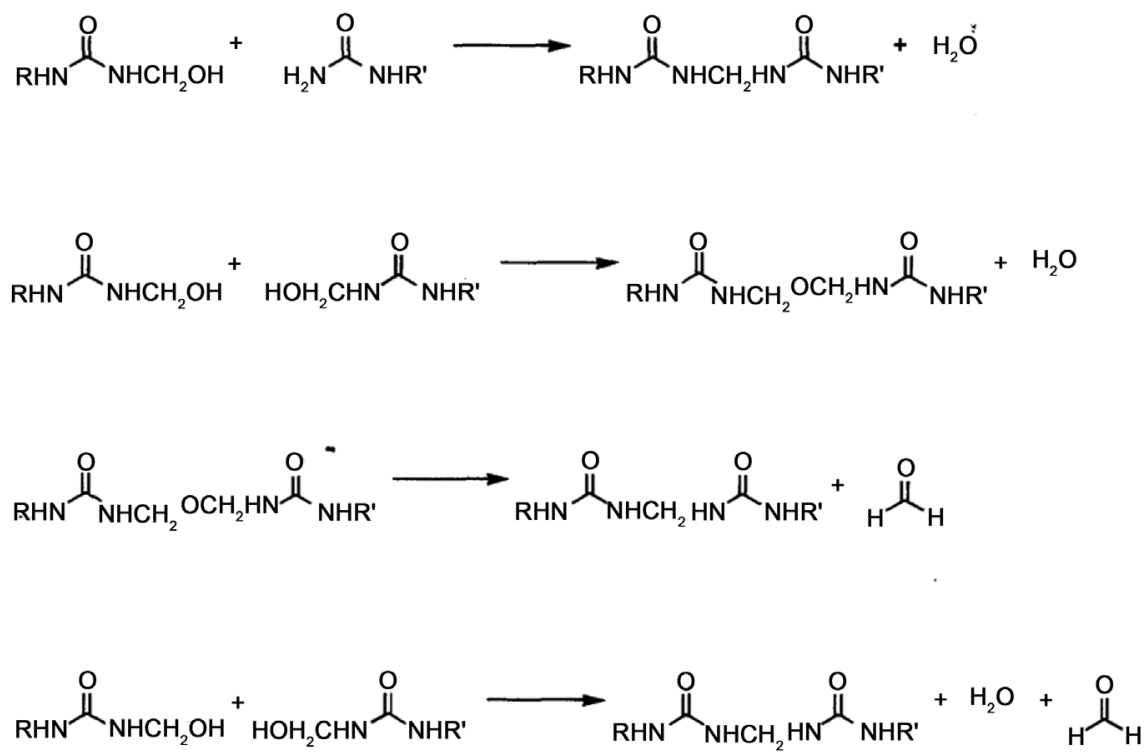

Figure 1. Condensation reactions. 
requires changes in the processing conditions, including the resin system used. The acidity of wood and the acid catalyst mixed in the adhesive play a very important role in providing (or generating) the optimum combined $\mathrm{pH}$ environment at the inter-phase during UF resin curing. To obtain optimum bond strength, the press time and temperature must be adjusted for the $\mathrm{pH}$ environment. If this correction is not precise, the glue line will be uncured or over-cured and will result in poor bond strength [12] [13] [14] [15] [16]. Gel time is a parameter which can correlate with process-ability of manufacturing of woodbased composite panels.

\section{Factors Affecting Gel Time of UF Resin}

Gel time of UF resin depends majorly on wood substrate, final properties of UF resin and formulation components.

\subsection{Wood Related Factors}

The four major components of woody biomass are: cellulose, hemicelluloses, lignin, and mineral components.

\subsubsection{Wood Extractives}

Some earlier studies have shown that the gel-time of UF adhesive is affected by wood extractives (Albriton and Short 1979). Another study revealed that the geltime of UF adhesive for a defined temperature is strongly dependent on the $\mathrm{pH}$ and the buffer capacity of wood extracts (Johns and Naizi 1980). Stefke and Dunky (2006) have noticed only slightly retarding effect of cold water wood extractives on curing of UF adhesive. More detailed information about this problem, especially concerning kinetic analysis of UF adhesive curing, was obtained by the differential thermal analysis (DTA) and differential scanning calorimetry (DSC) methods (Mizumachi 1973, Xing et al. 2005, Gao et al. 2008). Albritton and Short (1979) as well as Slay et al. (1980) reported that both ethanol-soluble and water-soluble extractives from pressure-refined fibers had a significant effect on UF resin gel time. Some researchers have shown that wood extractives [12] [17] [18] [19] [20] [21] strongly affect the gel time of UF resins. Barks showed lower $\mathrm{pH}$ values and higher acid and alkaline buffering capacities than wood of the same species, which may be due to its plentiful extractives.

\subsubsection{Wood pH Values (Fiber Acidity)}

Johns and Niazi (1980) and Peng and Li (1983) found that both wood buffering capacity and $\mathrm{pH}$ were strongly related to the gel time of UF resin mixed with wood flours. Park et al. (2001) revealed that fiber acidity strongly affected the internal bond strength (IB) of MDF panels boned with UF resin. Some researchers have shown that wood $\mathrm{pH}$ values, and buffering capacities [17] [18] [19] [20] [21] strongly affect the gel time of UF resins. Park et al revealed that the fiber acidity strongly affected the internal bond strength of medium-density fiberboard panels bonded with a UF resin [22]. Xing et al also reported that the $\mathrm{pH}$ value and buffering capacities of refined fibers affect some properties of me- 
dium-density fiberboard panels [23].

\section{Key Points related to wood $\mathrm{pH}$ :}

- $\mathrm{pH}$ and buffering capacity varies depending on the type of raw material..

- The softwood species studied had lower pH values than hardwood species.

- It indicated that with increasing tree age, poplar wood $\mathrm{pH}$ value increased, whereas acid buffering capacity decreased.

- It is known that soil is mostly acid, which explains why the $\mathrm{pH}$ value of most wood species is about 4 - 5 [12] [13] [14] [15] [16].

Wood $\mathrm{pH}$ value:

There are three procedures used, to obtain wood $\mathrm{pH}$ measurement.

1. Hot water extraction

2. Cold water extraction

3. Press chips to obtain pressed [17].

Buffering capacity of wood:

The aqueous extract is prepared by refluxing $25 \mathrm{~g}$ of dry furnish in $200 \mathrm{~g}$ of distilled water for $20 \mathrm{~min}$. Two replicates for each sample are prepared. After refluxing, the mixture is filtered through a filter paper using a vacuum. The aqueous extract is diluted to $500 \mathrm{ml}$ and cooled to room temperature before titration. All $\mathrm{pH}$ and buffering capacity measurements are made with a $\mathrm{pH}$ meter. Prior to each titration, the $\mathrm{pH}$ meter is calibrated with standardized buffer solution to a $\mathrm{pH}$ of either 4 or 7 , depending on the type of measurement to be done. After calibration, $100 \mathrm{ml}$ of extract solution is pipette into a $200-\mathrm{ml}$ beaker, the initial $\mathrm{pH}$ of the solution is recorded, and it is then titrated to a $\mathrm{pH}$ of 3 or 8 with nominal $0.025 \mathrm{~N} \mathrm{H}_{2} \mathrm{SO}_{4}$ or $0.025 \mathrm{~N} \mathrm{NaOH}$ solutions. For each titration, two replicate measurements are done. Thus, the initial $\mathrm{pH}$ value for each sample is the average of eight measurements, while each buffering capacity value $\left(\mathrm{mmol}^{\mathrm{y}}\right)$ is the mean of four determinations [12] [13] [14] [15] [16].

\subsubsection{Wood Particle Size/Fiber Dimensions}

Medved and Resniksuggested that reducing the wood particle size/fiber dimensions could reduce the gel time of UF resins [22]. Molecular weight of UF resin is designed by considering wood structural properties.

\subsection{Urea-Formaldehyde Resin Related Factors}

\subsubsection{Formaldehyde to Urea Ratio}

Formaldehyde to urea ratio has been dramatically lowered to approximately 1.02 to 1 by addition of urea at the end of synthesis and by other methods. It is also necessary to use more amount of catalyst when working with UF resin of lower Formaldehyde: Urea molar ratio, as the gel time of resin is slower. If there is less amount of free formaldehyde in system it will increase UF gel time and vice versa.

\subsection{2. \% Solid Content and $\mathrm{pH}$}

The gel time of the UF resin is strongly affected by its solid content and $\mathrm{pH}$ of UF resin. The gel time of the UF resin decreased with increasing resin solid con- 
tent. It is also depended on final $\mathrm{pH}$ of UF resin and $\mathrm{pH}$ also depended on \%solid content. The concentration of the UF resin decreased with decreasing solid content. More water in the system diluted the curing reactions and acted as an energy barrier to resin curing. Therefore, the cure rate decreased, and this resulted in a longer gel time. Thus, it is important to control the moisture content of raw materials in the manufacture of wood-composite products. The effect of the catalyst content on the gel time is more efficient for resins of lower solid contents than those of higher solid contents [24].

\subsection{Adhesive Formulation Related Factors}

\subsubsection{Type of Catalysts \& Amount of Catalysts}

Zanetti and Pizzi (2003) suggested that catalyst buffering action had strong effects on $\mathrm{pH}$, hardening speed, degradation reactions, and the degree of network formed of MUF resins. UO et al. (1998) suggested that the gel time of UF resin was directly correlated to $\mathrm{pH}$ and acid buffering capacity and inversely correlated to alkaline buffering capacity of six shrub species. The type and content of the catalyst directly affect UF-resin curing and the performances of final products. Poblete and Pinto reported that increasing the level of the catalyst reduces the $\mathrm{pH}$ and gel time of UF resins [25]. Myers suggested that the desirability of neutralizing an acidic cure catalyst after wood bonding reduced formaldehyde liberation and increased the durability of bonded products [26]. The results of Elbert show that formaldehyde emissions from UF resins and particleboards are affected by the type and content of the catalyst [27]. However, Lee et al. suggested that the amount of the hardener, which in their case varied from 0.8 to $3.2 \%$ (based on a resin with $66 \%$ solids), had practically no influence on the release of volatile acids from particleboards [28]. Pinto and Poblete showed that increasing the amount of the catalyst caused a reduction in the thickness swelling and water absorption and an improvement in the mechanical properties of particleboards [29]. However, the addition of an acid catalyst could increase the degradation of a cured UF resin in particleboards [30]. Xing et al. indicated that an optimal range of catalyst contents exists for the curing of UF resins [31]. Different acids are also used as curing catalyst.

Gel time measurement:

$\mathrm{UF}$ adhesive is diluted to $50 \%$ solid content and catalyst $\mathrm{NH}_{4} \mathrm{Cl}$ is added in range from $0.2 \%$ to $2 \% \mathrm{w} / \mathrm{w}$. The test tube is filled with $2 \mathrm{~g}$ of prepared adhesive as above and immersed into boiling water at constant stirring speed throughout the test. The elapsed time until the point when no further stirring is possible is defined as the gel time for a given adhesive sample.

\subsubsection{Other Polymer Addition}

Extensive study have been conducted to review the use of extenders for UF resin adhesive as several protein and starch based materials were in use. Most of the plywood industries are already using the extenders and also mixture of extender in their products which are cost effective.

Blending of UF resin with starch 
UF resin was reactively blended with various concentration of starch [32], esterified starch [33] [34] [35] and oxidized starch [36] as wood and wood composite adhesive. It is found that new system with UF-starch blending has advantages of low brittleness, low formaldehyde emission and water resistance characteristics [32]. In esterified-starch blended UF adhesive strength found to be comparable with synthetic resin adhesive system and content of free formaldehyde was lower than $0.3 \%$ [23] [24] [25]. Oxidized starch blended UF resin adhesive has good chemical stability, insulating properties, temperature resistance, aging resistance, oil resistance and mildew resistance and environmentally-friendly starch adhesive has no harm to the human body and can be applied to wood adhesion [37] [38] [39]. UF resin and modified starch mutual react and form a net structure, water resistance of starch glue was improved, and drying time was shortened [40] [41] [42]. So ultimately in above all systems few parts of UF were replaced by starch, because of which formaldehyde emissions were reduced and cost is maintained.

\section{Addition of cross-linker in starch-urea formaldehyde blends system}

UF-Starch blended adhesives were modified with different cross-linkers for improvement in performance properties. Starch adhesives were modified by isocyanate as cross-linker [43] [44] [45] [46] [47] [48] as well as starch adhesive with polyvinyl alcohol, borax, and carboxy methyl cellulose (CMC) as system [4] [49] [50] [51] [52] for wood composite can be prepared with isocyante as crosslinker, influence factors on the bonding strength and water resistance of starch adhesive were studied by different solid content, adding isocyanate and additives like PVA, Acrylic emulsion. Bonding strength and water resistance were improved significantly by adding additives and isocyanates to starch. An environmentally friendly wood adhesive was developed by cross-linking cornstarch-UF blend system with hexamethoxymethylmelamine (HMMM). It exhibited excellent mechanical properties comparable to many of the commercially available urea-formaldehyde plywood adhesives used for interior applications [53].

\section{Blending of UF resin with polyvinyl acetate emulsion adhesive}

The UF adhesive was modified with poly (vinyl acetate) to increase water resistance.

Modification UF with the use of various natural derived materials like tannin, lignin, cellulose, crude pyrolysis oil of wood, and soy have been carried out [54] [55] [56] [57]. Also combination of UF and MF is used for plywood industries.

\section{Conclusions}

Process-ability/manufacturing of wood composite like medium density board, particle board, plywood based on UF resin is a difficult task for manufactures because various factors that can interfere with the curing process. From this review paper, we concluded that gel time of urea formaldehyde resin is depended on following factors:

1) Wood extractives

2) Wood $\mathrm{pH}$ values (Fiber acidity) 
3) Wood particle size/fiber dimensions

4) Formaldehyde: Urea ratio

5) \%Solid content of UF resin

6) Type of catalysts \& Amount of catalysts

7) Other polymer addition

This factor should be considered during manufacturing of wood composite.

\section{References}

[1] Gao, Z., Wang, X.M., Wan, H. and Liu, Y. (2007) Curing Characteristics of UreaFormaldehyde Resin in the Presence of Various Amounts of Wood Extracts and Catalyst. Journal of Applied Polymer Science, 107, 1555-1562. https://doi.org/10.1002/app.27205

[2] Dunky, M. (1998) Urea-Formaldehyde (UF) Adhesive Resins for Wood. International Journal of Adhesion and Adhesives, 18, 95-107.

[3] Xing, C., Zhang, S.Y., Deng, J. and Wang, S. (2006) Urea-Formaldehyde-Resin Gel Time as Affected by the $\mathrm{pH}$ Value, Solid Content, and Catalyst. Journal of Applied Polymer Science, 103, 1566-1569. https://doi.org/10.1002/app.25343

[4] Whitfield, R.M., Brown, F.C. and Low, R. (2007) Socio-Economic Benefits of Formaldehyde to the European Union (EU25) and Norway. Global Insight, Lexington.

[5] Conner, A.H. (1996) Urea-Formaldehyde Adhesive Resins. Polymeric Materials Encyclopedia, 128, 8496-8501.

[6] Hse, C.Y., Xia, Z.Y. and Tomita, B. (1994) Effects of Reaction pH on Properties and Performance of Urea-Formaldehyde Resins. Holzforschung, 48, 527-532. https://doi.org/10.1515/hfsg.1994.48.6.527

[7] Stuligross, J. and Koutsky, J.A. (1985) A Morphological Study of Urea-Formaldehyde Resins. Journal of Adhesion, 18, 281-299. https://doi.org/10.1080/00218468508080464

[8] Xing, C., Riedl, B., Cloutier, A. and Shaler, S.M. (2005) Characterization of UreaFormaldehyde Resin Penetration into Medium Density Fiberboard Fibers. Wood Science and Technology, 39, 374-384. https://doi.org/10.1007/s00226-005-0294-4

[9] Myers, G.E. (1981) Investigation of Urea-Formaldehyde Polymer Cure by Infrared. Journal of Applied Polymer Science, 26, 747-764. https://doi.org/10.1002/app.1981.070260301

[10] Troughton, G.E. (1969) Accelerated Aging of Glue-Wood Bonds. Journal of Wood Science, 1, 172-176.

[11] Myers, G.E. (1982) Hydrolytic Stability of Cured Urea-Formaldehyde Resins. Journal of Wood Science, 15, 127-138.

[12] Albritton, R.O. and Short, P.H. (1979) Effects of Extractives from Pressure-Refined Hardwood Fiber on the Gel Time of Urea-Formaldehyde Resin. Forest Products Journal, 29, 40-41.

[13] Guo, A.L., Zhang, H.S., Feng, L.Q., Gao, X.X. and Zhang, G.L. (1998) pH Value and Buffering Capacity of 6 Shrub Species and Relevant Effect on Curing Time of UF Resin. China Wood Industry, 12, 18-20.

[14] Johns, W.E. and Niazi, K.A. (1980) Effect of pH and Buffering Capacity of Wood on the Gelation Time of Urea-Formaldehyde Resin. Wood and Fiber Science, 12, 255 263.

[15] Park, B.D., Kim, Y.S. and Riedl, B. (2001) Effect of Wood-Fiber Characteristics on Medium Density Fiberboard (MDF) Performance. Journal of the Korean Wood Science and Technology, 29, 27-35.

[16] Peng, H.Y. and Li, J. (1983) Effect of $\mathrm{pH}$ and the Buffering Capacity of Economic Wood Species Growing in Northeast on the Gel Time of Urea-Formaldehyde Resin. J. North East for Ins China, 11, 100-105. 
[17] Sithole, B. (2005) New Method of Measuring the pH of Wood Chips. 59th APPITA Annual Conference and Exhibition: Incorporating the 13th ISWFPC, Auckland, 16-19 May 2005, 391-396.

[18] Xing, C., Riedl, B. and Cloutier, A. (2004) Measurement of Urea-Formaldehyde Resin Distribution as a Function of MDF Fiber Size by Laser Scanning Microscopy. Wood Science and Technology, 37, 495-507. https://doi.org/10.1007/s00226-003-0195-3

[19] Slay, J.R., Short, P.H. and Wright, D.C. (1980) Catalytic Effect of Extractives from Pressure-Refined Hardwood Fiber on the Gel Time of Urea-Formaldehyde Resin. Forest Products Journal, 30, 22-23.

[20] Pizzi, A., Mtsweni, B. and Parsons, W.J. (1994) Wood-Induced Catalystic Activation of PF Adhesives Auto Polymerization vs. PF/Wood Covalent Bonding. Journal of Applied Polymer Science, 52, 1847-1856. https://doi.org/10.1002/app.1994.070521302

[21] Xing, C., Deng, J., Zhang, S.Y., Riedl, B. and Cloutier, A. (2005) DSC Characterization of UF Resin Curing Behavior as Affected by Less Desirable Wood Material and Catalyst Content. Journal of Applied Polymer Science, 98, 2027-2032. https://doi.org/10.1002/app.22118

[22] Mao, A., Hassan, E.B. and Kim, M.G. (2013) Investigation of Low Mole Ratio UF and UMF Resins Aimed at Lowering the Formaldehyde Emission Potential of Wood Composite Boards. Bioresources, 8, 2453-2469.

https://doi.org/10.15376/biores.8.2.2453-2469

[23] Balaban, M. and Uçar, G. (2001) The Correlation of Wood Acidity to Its Solubility by Hot Water and Alkali. Holz als Roh-und Werkstoff, 59, 67-70. https://doi.org/10.1007/s001070050476

[24] Gu, J.Y., Wei, S.Y. and Zhu, L.B. (2004) Study on Curing Agents Systems of UreaFormaldehyde Resin. China Adhesives, 13, 4-8.

[25] Poblete, H.W. and Pinto, A.S. (1993) Advances on the Effect of the Catalyst in the Curing of Urea Formaldehyde in Tepa Boards. Forest v., 14, 55-61.

[26] Myers, G.E. (1990) Formaldehyde Liberation and Cure Behavior of Urea-Formaldehyde Resins. Holzforschung, 44, 117-126. https://doi.org/10.1515/hfsg.1990.44.2.117

[27] Park, B.D. and Causin, V. (2013) Crystallinity and Domain Size of Cured UreaFormaldehyde Resin Adhesives with Different Formaldehyde/Urea Mole Ratios. European Polymer Journal, 49, 532-537.

[28] Lee, T.W., Roffael, E., Dix, B. and Mitertzsch, H. (1994) Influence of Different Catalyst Systems on the Hydrolytic Stability of Particleboards Bonded with Unmodified and Modified UF-Resins. Holzforschung, 48, 101-106.

https://doi.org/10.1515/hfsg.1994.48.s1.101

[29] Hse, C.Y., Fu, F. and Pan, H. (2008) Melamine-Modified Urea Formaldehyde Resin for Bonding Particleboards. Forest Products Journal, 58, 56-61.

[30] Robitschek, P. and Christensen, R.L. (1976) Degradation Phenomena in Urea Formaldehyde Resin-Bonded Particleboard. Forest Products Journal, 12, 43-46.

[31] Xing, C., Deng, J., Zhang, S.Y., Riedl, B. and Cloutier, A. (2005) Differential Scanning Calorimetry Characterization of Urea Formaldehyde Resin Curing Behavior as Affected by Less Desirable Wood Material and Catalyst Content. Journal of Applied Polymer Science, 98, 2027-2032. https://doi.org/10.1002/app.22118

[32] Dimas, B.J., Osemeahon, S.A., Maitera, O.N. and Hotton, A.J. (2013) Influence of Starch Addition on Properties of Urea Formaldehyde/Starch Copolymer Blends for Application as a Binder in the Coating Industry. Journal of Environmental Chemistry and Ecotoxicology, 5, 181-189.

[33] Xu, Z., Hua, S. and Tu, Y. (2013) Esterified-Starch Modified Urea Formaldehyde Adhesive. CN 102898987 A 12, Jan 30, 2013. 
[34] Liu, R. (2013) Modified Urea-Formaldehyde Resin. CN 103360559 A 13, Oct 23, 2013.

[35] Zhu, L. (2014) Preparation Method for High-Strength Water-Resistant Starch Adhesive for Corrugated Paperboards. CN 104119816 A 14, 29 Oct, 2014.

[36] Ni, K. (2014) Oxidized Starch Modified Urea-Formaldehyde Resin Adhesive. CN 103911103 A 15, 09 July 2014.

[37] Chen, Y. (2014) Method for Producing Urea-Formaldehyde Resin Adhesive. CN 104178070 A 16, 03 Dec., 2014.

[38] Li, J., Shen, K., Cai, J., Lai, Q. and Zheng, X. (2010) Environmentally-Friendly Starch Adhesive. CN 101735741 A 17, 16 Jun 2010.

[39] Park, B.D., Kang, E.C. and Park, J.Y. (2006) Effects of Formaldehyde to Urea Mole Ratio on Thermal Curing Behavior of Urea-Formaldehyde Resin and Properties of Particleboard. Journal of Applied Polymer Science 101,1787-1792. https://doi.org/10.1002/app.23538

[40] Yu, S. and Zhang, H. (2008) Starch Adhesive for Producing Highly Intensified Water-Proof Corrugated Paper. CN 101134881 A, 5 Mar 2008.

[41] Liu, Y., Zhang, Y. and Li, Q. (2014) Environmental Moisture MDF with Urea-Formaldehyde Resin Adhesive and Composite Additives and Production Methods. CN 102408855 B, 18 Jun, 2014.

[42] Lv, Z., Duan, X.L., Xu, S., Deng, Z., Zhou, Y. and Jiang, Z. (2014) Manufacturing Method of Low-Formaldehyde-Release-Amount Plywood. CN 103484046 B, 31 Dec., 2014.

[43] Wieland, S., Pizzi, A., Grigsby, W., Warnes, J. and Pichelin, F. (2007) Microcrystallinity and Colloidal Peculiarities of UF/Isocyanate Hybrid Resins. Journal of Applied Polymer Science, 104, 2633-2636. https://doi.org/10.1002/app.24757

[44] Gu, J.Y., Zuo, Y.F., Zhang, Y., Tan, H.Y., Zhu, L.B. and Shen, J. (2010) Preparation of Plywood Using Starch Adhesives Modified with Isocyanate. Applied Mechanics and Materials, 26, 1065-1068. https://doi.org/10.4028/www.scientific.net/AMM.26-28.1065

[45] Li, L.H., Liu, G.J. and Zhang, G.X. (2008) The Latest Progress in Study on StarchBased Adhesives. Chemistry and Adhesive, 30, 50-53.

[46] Liu, Y.H., Ruan, R.S. and Zhang, J.S. (2005) Research Situation of Starch Based Wood Adhesives. Chemistry and Adhesive, 27, 358-361.

[47] Zhang, Y.H., Gu, J.Y. and Tan, H.Y. (2009) Preparation of the Plywood Using UF Resin Modified with Blocked Isocyanates as Bonding Agent. China Forest Products Industy, 36, 17-19.

[48] Huang, Y.B. and Huo, Q.Y. (2006) The Application of Isocyanates Adhesive in Timber Industry. Journal of Heilongjiang Ecological Engineering Vocational College, No. 6, 34-35.

[49] Qiao, Z., Gu, J., Lv, S., Cao, J., Tan, H. and Zhang, V. (2015) Preparation and Properties of Isocyanate Prepolymer/Corn Starch Adhesive. Journal of Adhesion Science and Technology, 29.

[50] Shi, J. (2007) Starch Based Wood Adhesive API and Curing and Aging Mechanism. Journal of Northeast Forestry University, 90-123.

[51] Shi, J.Y. and Tang, Y.Y. (2010) Study on the Rice Straw Particleboard by StarchBased API Adhesive. Advanced Materials Research, 113, 1017-1020. https://doi.org/10.4028/www.scientific.net/AMR.113-116.1017

[52] Du, S. and Zhang, C. (2003) Study on Modified Starch of Non-Formaldehyde Adhesive. Journal of Chinese Adhesive, 10, 11-13.

[53] Imam, S.H., Mao, L.J., Chen, L. and Greene, R.V. (1999) Wood Adhesive from Crosslinked Poly (Vinyl Alcohol) and Partially Gelatinized Starch: Preparation and Properties. Starch-Starke, 51, 225-229. https://doi.org/10.1002/(SICI)1521-379X(199906)51:6<225::AID-STAR225>3.0.CO; $\underline{2-\mathrm{F}}$ 
[54] Mizumachi, H. (1973) Activation Energy of the Curing Reaction of Urea Resin in the Presence of Wood. Wood Science and Technology, 6, 14-18.

[55] Yang, I., Kuo, M. and Myers, D. (2006) Bond Quality of Soy-Based Phenolic Adhesives in Southern Pine Plywood. JAOCS, 83, 231-237. https://doi.org/10.1007/s11746-006-1198-7

[56] Papadopoulos, A.N., Hill, C.A.S., Traboulay, E. and Hague, J.R.B. (2002) Isocyanate Resins for Particleboard: PMDI vs. EMDI. Holz als Roh-und Werkstoff, 81-83. https://doi.org/10.1007/s00107-001-0275-8

[57] Ballerini, A., Despres, A. and Pizzi, A. (2005) Non-Toxic, Zero Emission Tannin-Glyoxal Adhesives for Wood Panels. Holz als Roh-und Werkstoff, 477-478. https://doi.org/10.1007/s00107-005-0048-x

Submit or recommend next manuscript to SCIRP and we will provide best service for you:

Accepting pre-submission inquiries through Email, Facebook, LinkedIn, Twitter, etc. A wide selection of journals (inclusive of 9 subjects, more than 200 journals) Providing 24-hour high-quality service User-friendly online submission system Fair and swift peer-review system Efficient typesetting and proofreading procedure Display of the result of downloads and visits, as well as the number of cited articles Maximum dissemination of your research work

Submit your manuscript at: http://papersubmission.scirp.org/ Or contact ojpchem@scirp.org 